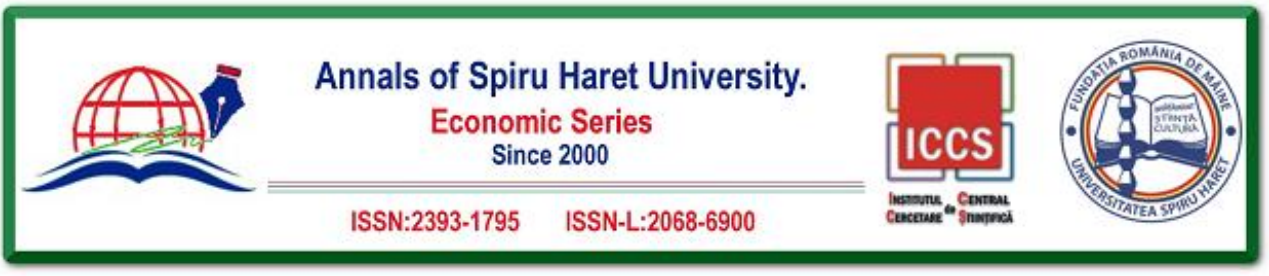

Issue 3/2018

\title{
HOUSEHOLDS' PERCEPTION OF CLIMATE CHANGE EFFECTS IN RURAL ROMANIA
}

\author{
Camelia SURUGIU ${ }^{1}$, Marius SURUGIU ${ }^{2}$, Raluca MAZILESCU ${ }^{3}$, \\ Anca CRISTEA ${ }^{4}$, Ileana MARGINEAN ${ }^{5}$ \\ ${ }^{1}$ Faculty of Administration and Business, University of Bucharest, 4-12 \\ Bd. Regina Elisabeta, Bucharest, Romania, \\ Email: cameliasurugiu@gmail.com \\ 2, 3, 4, 5 Institute of National Economy, Romanian Academy, 13 Calea 13 \\ Septembrie, Bucharest, Romania,Email: mariussurugiu@yahoo.com, \\ ralucamazilescu@gmail.com,lcancacristea@yahoo.com, \\ ileanamarginean40@gmail.com
}

How to cite: SURUGiU, C., SURUGiU, M., MAZILESCU, R., CRISTEA, A., MARGINEAN, I. (2018). "Households' Perception of Climate Change Effects in Rural Romania." Annals of Spiru Haret University. Economic Series, 18(3), 43-57, doi: https://doi.org/10.26458/1833

\begin{abstract}
This paper is focused on the analysis of the impact of climate change on the households from rural Romania. Climate change may have an impact on different sectors of the economy, such as agriculture, food industry, energy sector, tourism, etc. Also, the impact is felt by households. In rural regions of Romania, the households are already facing various risks, related to lack of income, and also related to ageing population. This study aimed to underline how rural people relate to the climatic conditions with emphasis on the trend of major change in the various aspects of the weather, sources used to find information on climate change, reliability level of the climate change information provided by various sources, the possibility to adopt measures to tackle the effects of climate change, and so on. A number of 100 copies of the questionnaire were distributed among households in a rural area of Dâmbovița County, Romania - Petrești commune - in April, 2018, with the main purpose to test it. The respondents were selected randomly. Poor households are vulnerable to climate change because low income cannot provide a satisfactory degree of access to services needed in the protection against threats.
\end{abstract}




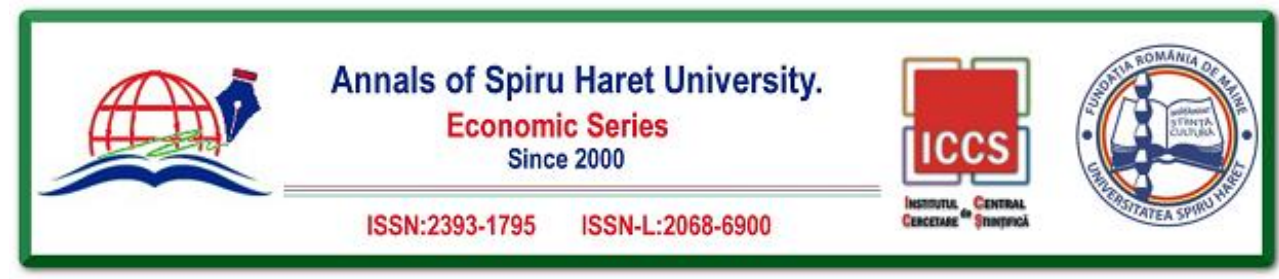

Issue $3 / 2018$

Various adaptation strategies may be used by households confronted with negative effects of climate change.

Keywords: climate change; rural areas; Romania.

JEL Classification: $\mathrm{Q}_{54}$

\section{Introduction}

Climate change is expressed through droughts, floods, less rainy days during the year, extreme heat weaves, generating serious effects on agricultural and forestry activities of households in rural areas. In developing countries, rural areas will be altered by climate change, especially in regions depending on subsistence agriculture and where the population is not properly equipped in order to adapt [Seaman et al., 2014]. Uncertainty in respect to assuring water and food supplies ranks among the highest threats for households. Poor households need more assistance to reduce their degree of exposure to climate change and to cope with its negative effects [Ndhleve et al., 2014].

The vulnerability of rural communities will increase as they depend on climate sensitive economic sectors, such as agriculture and forestry, and their adaptation measures are limited due to scarce financial and human, physical, social and natural resources [Ncube et al., 2016]. Climate change will induce behaviour changes of households, which are very important to be investigated as a starting point for reducing the greenhouse gas emissions [Riedy, 2007].

In the case of Romania, there are various studies analysing the impact of climate change, such as:

- The challenges for agriculture within the context of climate change - South Oltenia is a region affected by aridity and drought phenomena, ranking the $2^{\text {nd }}$ in Romania, after the Eastern Dobrogea Region [Balteanu et al., 2013]; the territory with an increased risk for drought contains large areas in southern Oltenia as this region is the most exposed to these phenomena in Romania; in Oltenia plain, stifling heat has a high frequency, the largest in the whole country, together with Teleorman plain and the Danube river up to Giurgiu [Hurduzeu et al., 2014]; in the southern plains of Romania, drought is a phenomenon that occurs on regular basis and farmers are experiencing severe losses [Ioan \& Rădulescu, 2015]; extreme weather events (storms, floods, droughts) will occur more frequently, and related risks and damages 


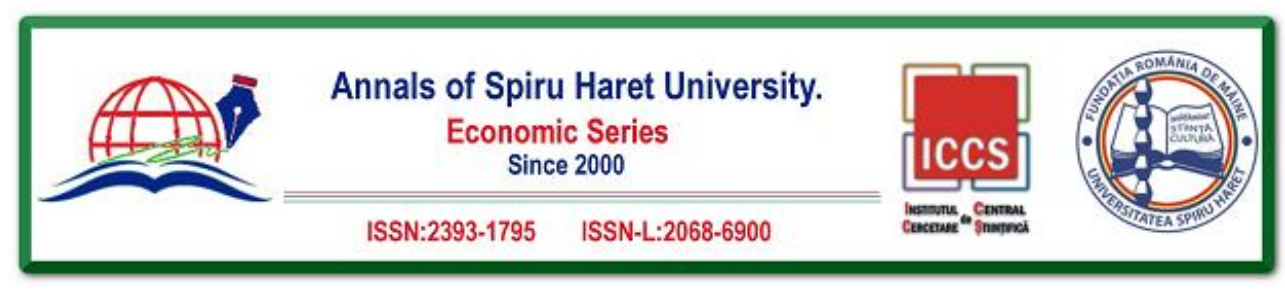

Issue 3/2018

may become more significant [Slave \& Vizireanu, 2015]; the upward trend of air temperature determined the intensification of dry periods and increased demand for water in agriculture from Oltenia Plain [Ontel \& Vladut, 2015]; in general, severe water deficits for agricultural crops are likely to be experienced in Timiş Plain [Mitrică et al., 2015]; the main climate adaptation measure considered crucial by the farmers in the Bărăgan Plain is the rehabilitation/construction of irrigation systems; this region is exposed to droughts, with negative impact on crop yields [Sima et al., 2015]; in Oltenia and Muntenia regions there is a significant increase in the frequency and duration of heat stress [Micu et al., 2017];

- The assessment of the climate change impact on water resources and life quality - the climate change may bring in Romania also a change in the configuration of the agricultural crops, an increase of the vulnerability of the humans and a change in the quality of life (health, safety and ownership problems), the occurrence of droughts, heat waves and floods, an impact on water quantity and quality, and so on [Curseu et al., 2009];

- The impact of climate change on climatic indicators - in Transylvanian Plain, in the past few years, climate change had an important impact on these indicators [Rusu et al., 2014];

- The climate change impact in Romania, with vulnerability and adaptation options - among the most affected by climate change are maize crops in the southern part of the country, forest species growing in the plains and hilly zones, and water resources where demands could exceed their availability [Cuculeanu et al., 2002]; there is a need to put into practice the optimal measures for preventing climate change [Constantinescu, 2018].

In Romania, climate change is becoming more and more visible and its effects cannot be overlooked. Therefore, measures must be adopted to tackle the causes, knowing the risks of climate change and the benefits of mitigation measures.

\section{Literature Review}

The effects of climate change may represent decreases in food and non-food crops, but also increased prices, and deterioration of population welfare [Dasgupta et al., 2014]. For rural households, food security is one of the most frequent threats. The reduction of crops and dairy production generates a decrease in the incomes of the population [Poudel et al., 2017]. Climate change has an adverse impact on the livelihoods of rural communities and the state departments should launch awareness campaigns regarding adoption of different adaptation strategies [Luqman et al., 


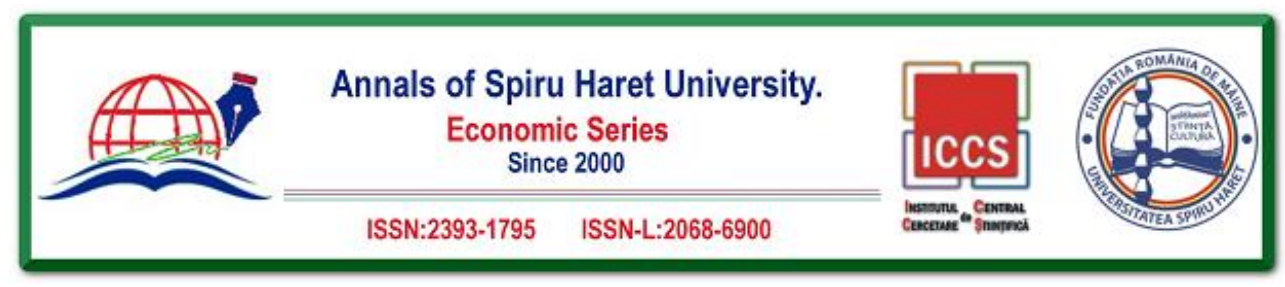

Issue 3/2018

2017]. Awareness programs on climate change should be intensified, and sustainable adaptation strategies employed by the rural people should be strengthened [Abaje et al., 2016]. The rural farmers are highly vulnerable to the consequences of climate change, to droughts, excessive temperatures and heavy rainfall [Maluleke \& Mokwena, 2017]. The change in climate pattern has a negative impact on farming and the vulnerability of farm households is related to the lack of knowledge and financial resources [Shrestha et al., 2017].

Gurgu (2010) discussed various aspects related to climate change, underlying that this phenomenon is one important concern at the global level, both governments and people being responsible in shaping the future. In some areas, the impact of climate change on the livelihoods represents a major threat because it generates not just transformations in physical geography of the area, but also losses in flora and fauna, in the natural habitat in which local communities are living. Climate change will represent a threat for food reserves because traditional fruits are disappearing and weather will not favour indigenous crops [Dube \& Phiri, 2013].

In regions where livelihoods are assured by incomes obtained in different activities (not only those from agriculture, but also from hunting, harvesting wild food or having a stable job), households are less vulnerable to climate change and more adapted to face different risks associated with extreme events [Seaman et al., 2014]. Because the livelihoods of smaller farmers will be seriously affected, several types of strategies are needed to cope during different periods of time, in order to become more resilient to climate change [Umar et al., 2014]. Adaptation measures are necessary in order to face climate change, and these may include adjustments in farming methods (i.e. using less water-consuming crops, livestock less vulnerable to water and food pressure) and even finding other sources of income besides agriculture [Poudel et al., 2017]. Adjusted strategies such as livestock mobility, animal restocking, etc. can support local livelihoods [Berhe et al., 2017]. A measure to manage food insecurity may refer to adopting intensive agricultural practices with irrigation-based system of farming, as a method of producing crops with required moisture under various climatic conditions [Olabode \& Adeleke, 2017].

Ofoegbu et al. (2017) showed that, in the rural areas, the efficiency of strategies for climate change adaptation largely depends on the socio-economic and demographic characteristics of population, including aspects such as the level of skills, education, health, but also on the infrastructure. Antwi-Agyei et al. (2013) underlined that vulnerable communities have limited livelihood opportunities, and social connectivity is higher, which provide them opportunities to take advantage upon various changes occurring in the economic and natural environment. 


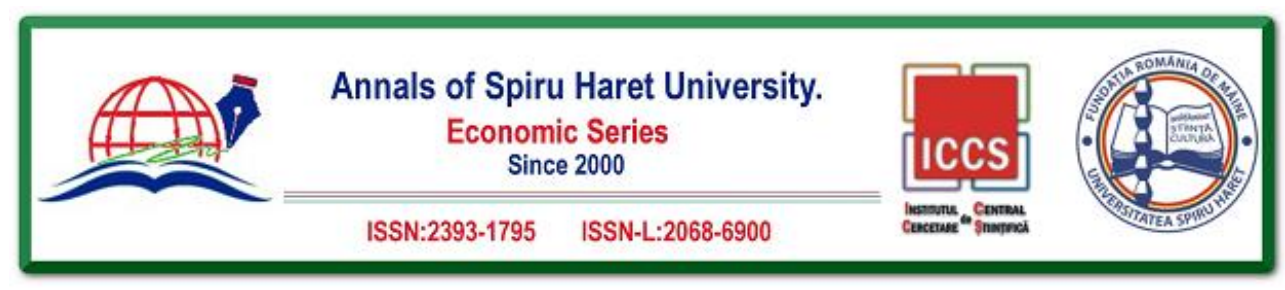

Issue 3/2018

Farming population, negatively affected by climate change due to decreases in both incomes and food security, will need to adapt through awareness and promotion of more efficient tools to use the available resources, and through education [Karfakis et al., 2012]. Moreover, policy measures have to be adopted in order to increase the incomes of farmers, and to minimize the damages of extreme events through mitigation strategies [Deressa et al., 2009].

Furthermore, adaptation strategies to climate change need to be tailored to the local needs and specificity, and upgraded all the time to the realities shaped by the effects of climate change. In order to increase the resilience of local communities, it is necessary to use not only a bottom-up, but also a top-down approach, a transformational adjustment for rural residents, households and government [Pettengell, 2010]. Kaushik and Sharma (2015) developed an analysis on climate change and rural livelihoods-adaptation and vulnerability topic, underlying that local strategies and traditional knowledge need to be used in synergy with government and local interventions.

Haque et al. (2014) argued that there is a need for coordination, preparation and management from local communities, households and different institutions, to prevent the negative effects of climate change, and to avoid their transformation into disasters. Ludena and Yoon (2015) indicated that farmers don't have enough access to some types of capital markets and technical know-how, as tools for adaptation to climate change, and therefore, they need to organize in collective arrangements and to be supported in their action through various tools.

Some previous studies underlined that local communities are not even aware of the concept of climate change [Dube \& Phiri, 2013; Ndhleve et al., 2014]. Consequently, development agencies, governments, councillors are needed to enhance public awareness regarding climate change effects, to educate local communities and to increase knowledge about this phenomenon [Ndhleve et al., 2014].

In rural areas there are high rates of vulnerable population, economic uncertainty, less resilient infrastructure, and lower levels of access to community and emergency services than in urban areas [Houghton et al., 2017]. Climate change may amplify some distinctive features, with differences in temperature in urban areas, which are higher than in rural areas [Zeleňáková et al., 2015]. Interactions between local and higher level institutions may affect the capacity of a community to respond to change [Brown \& Sonwa, 2015].

Climate change is related to extreme events with important impact on the life of rural people, and not only. It seems that the impact is different in rural and urban 


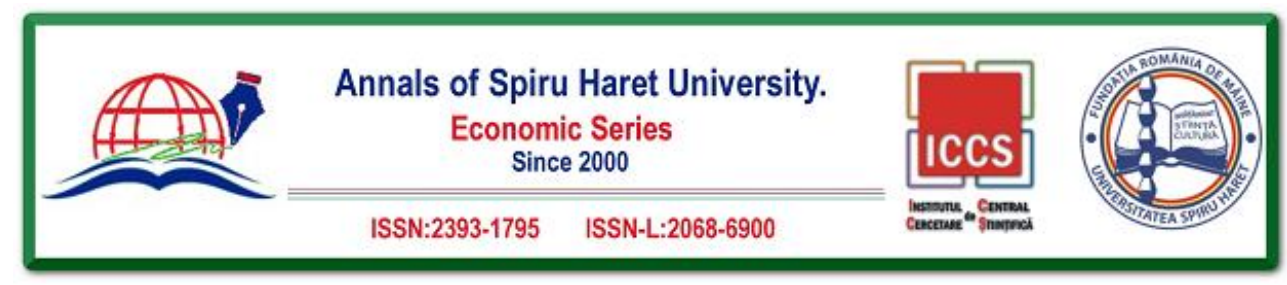

Issue 3/2018

areas. Nonetheless, in order to prevent the amplification of negative effects, it is important for each person to adopt a daily behaviour and measures to reduce the personal impact on the environment, regardless of the place of living. Thus, it is important to reduce the greenhouse gas emissions, by saving energy, by recycling waste, and so on.

\section{Methodological Approach}

This paper presents the results of applying a questionnaire based on 14 questions, used to gather important data from rural households. The questions are focusing on identifying the opinion of households on the impact of climate change on daily activities. This questionnaire contains questions with only one possible answer and multiple choice questions, and a Likert-type scale is used.

Generally speaking, questionnaires are used for survey research, to determine a current status or situation. The analysed situation in this paper is the impact of the climate change on rural households from Romania. The questionnaire (Questionnaire regarding the assessment of the climate change impact on rural areas households) was applied to respondents from Petrești commune, Dâmbovița County, Romania, in April 2018, and the main purpose was to test it. The data were collected at the Commune Hall. Petrești commune is located in the south-west of Dâmboviţa County and comprises several villages: Petrești (residence of the commune), Coada Izvorului, Gherghești, Greci, Ionești, Potlogeni-Deal, and Puntea de Greci. According to the Population and Housing Census (2011), the population of Petrești commune amounts to 5.791 inhabitants.

Agricultural surface of the commune is around $80-90 \%$, the production of vegetables being an important tradition. Near the village of Petreşti there is a natural reservation (Poiana Narciselor, a natural protected area of $15 \mathrm{ha}$ ).

The research is quantitative, assuming that the questionnaire is sent to a large number of persons, and the data are accurate, being statistically analysed. The research tool is the questionnaire used in data collection from households.

Considering the audience, the respondents were persons of various ages and income levels. The data collection method was the personal interview (face-to-face), and 100 questionnaires were applied, all being validated (100 persons, 54 men and 46 women). The surveyed population is comprising the household representatives, generally over 25 years old (only two persons are under 25 years old).

The objectives of the research are as follows:

a) To determine the awareness level regarding the climate change; 


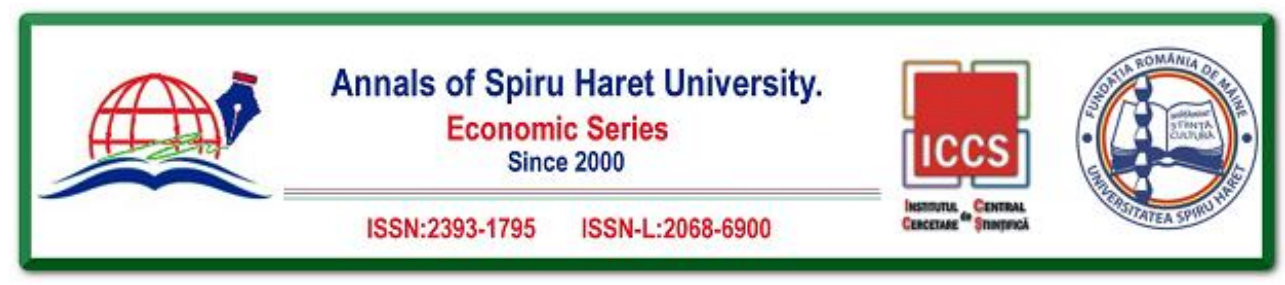

Issue 3/2018

b) To identify household perceptions about the effects of climate change;

c) To determine the sources of information that provide reliable data on the effects of climate change;

d) To identify the stakeholders responsible to tackle the effects of climate change;

e) To identify the possibility of taking measures to tackle the effects of climate change.

The research hypotheses are as follows:

1) In general, households are aware of the presence of climate change and its effects (on daily activities);

2) In general, households have perceived important changes of some aspects of the weather;

3) In general, households are or will be affected by climate change;

4) In general, households are particularly confident about the climate change information provided by specialists in the field;

5) A high percentage believes that measures can be taken to tackle the effects of climate change;

6) Household representatives believe that local public administration is the main stakeholder that should be involved in taking measures to tackle the effects of climate change.

According to the results, the hypotheses 1 to 4 were confirmed. The hypothesis 5 and the hypothesis 6 were not confirmed.

The design and testing of the questionnaire have been developed to ensure that the survey tool is suitable for the audience. This represents a very important step in developing the final version of the questionnaire, allowing the improvement of some unclear questions and detecting errors beforehand.

Following the field testing, the questionnaire will be improved, to include some questions related to the objectives such as:

- Determining the awareness level regarding the causes of climate change;

- Identifying the opinion of households regarding some climate change mitigation policies.

The new format of the questionnaire will be used in a future research. Thus, the future research will gather more information from all household members to provide a comprehensive analysis of the rural environment confronting the climate change aspects.

\section{Results and Discussions}

The questions focused on the following: 


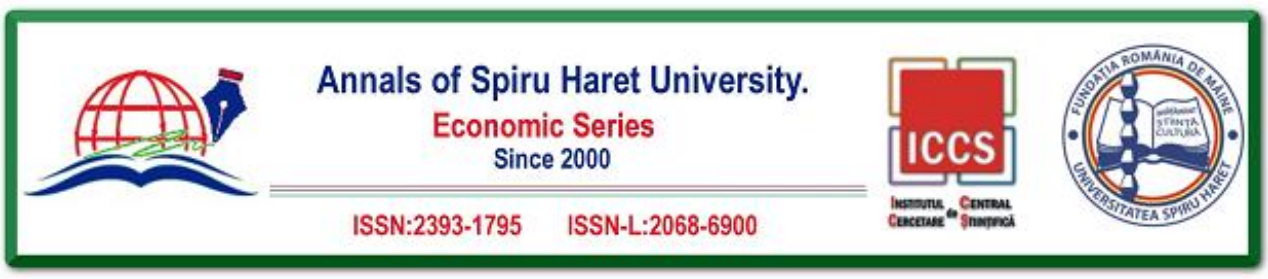

Issue $3 / 2018$

- Major changes in various aspects of the weather (types of wind, quantity and type of precipitation, etc.);

- Sources used by the respondent to find information on climate change;

- Reliability level in the climate change information provided by friends, family members, specialists, representatives of local public administration, TV / radio / newspapers / magazines;

- The future impact of the climate change;

- The possibility to adopt measures to tackle the effects of climate change;

-Identifying the organizations responsible in adopting measures to tackle the effects of climate change.

The analysis of data collected underlines that a relatively high percent of respondents heard about "climate change" (53\%), while 13\% of them declared they never heard of this phenomenon. The rural persons are aware of the climate change, and they are interested in this topic. This also underlines the need for awareness strategies.

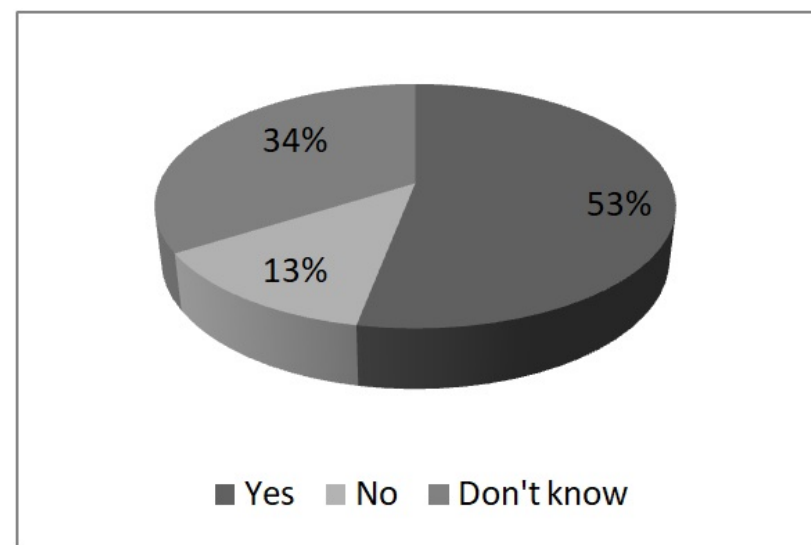

Fig. 1. The Distribution of Respondents According to the Answers of the Question: "Have You Ever Heard about Climate Change?"

Source: developed by authors based on survey data

Half of the respondents stated that they have perceived important changes of some aspects of the weather (types of wind, the amount and type of precipitation, etc.). At the same time, $16 \%$ of them didn't notice any important changes in the 


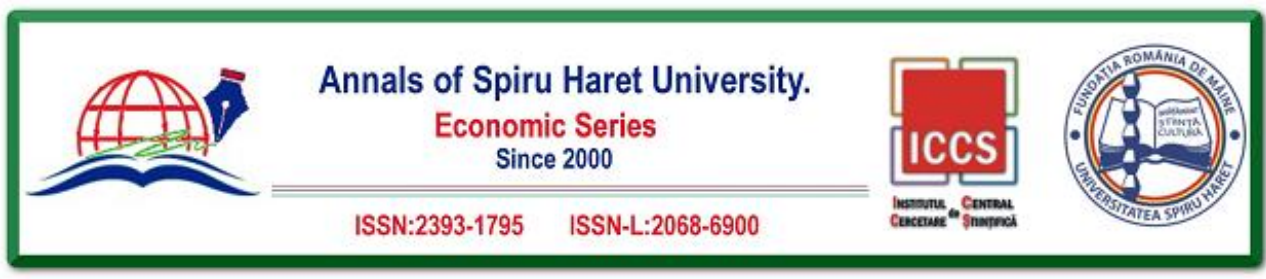

Issue 3/2018

weather. This important percentage of $50 \%$ represents the persons who carry out specific activities in the rural areas and who are able to see the changes in the environment they live in.

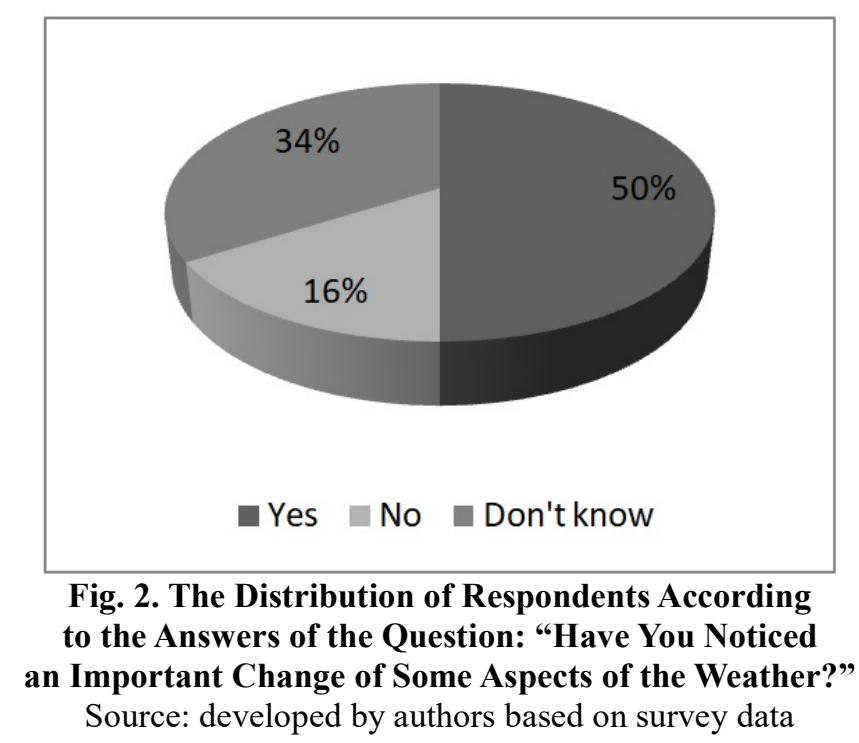

Most of the information on climate change reached the audience (respondents) via television, and to a much lesser extent via radio, the Internet, newspapers, and magazines. The result highlights the importance of this information channel (television) for rural persons, where they can easily find news about climate change. However, according to the respondents, they have the highest confidence in the information provided by specialists, followed by members of the local public administration, TV / radio, newspapers, and magazines.

Regarding the effects of climate change at the individual level, only $43 \%$ of the respondents declared that they are or will be affected, while $11 \%$ considered they will not experience these effects. A high proportion is represented by those who responded that they do not know if the changes in various aspects of the weather had or will have an influence on them. This might be caused by the insufficient level of information held by rural people concerning climate change. 


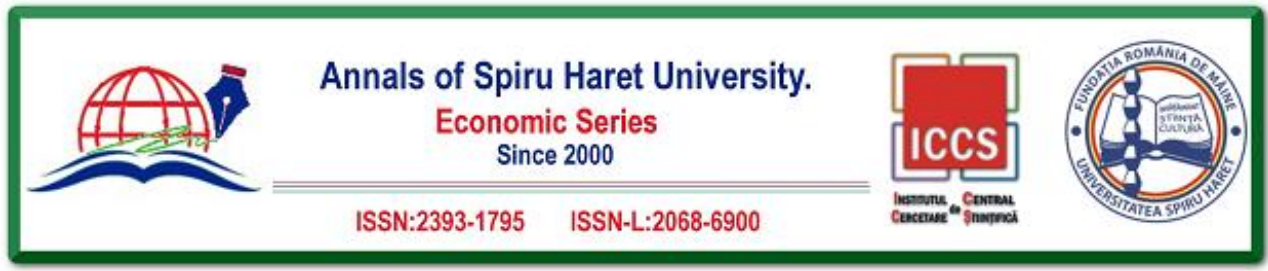

Issue $3 / 2018$

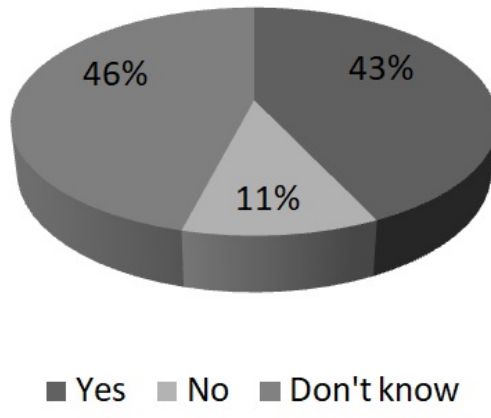

Fig. 3. The Distribution of Respondents According to the Answers of the Question: "Do You Think the Climate Change Affects You or Will Affect You in the Future?" Source: developed by authors based on survey data

Of those who consider that climate change is already affecting them, or will affect them in the future, a high percentage indicated that they have suffered losses regarding the quantity and quality of crops due to high temperatures / droughts, and increasing incidence and severity of floods in gardens, orchards, and fields. Only a small percentage of the interviewed persons considered that measures can be taken to tackle the effects of climate change. This might underline, again, the insufficient information held by rural people concerning climate change. The high share of those who answered that they do not know if climate change can be mitigated through practical measures indicates the need to make this topic more widely known to the general public. The respondents mentioned businesses and industry, followed by local public administration, as being responsible for taking measures to tackle the effects of climate change.

Raising awareness on climate change and providing information to the population and to the decision-maker are important steps in the attempt of tackling climate change effects and adapting to climate change.

It is important to improve the access of vulnerable persons to the process of adopting measures and to the information on climate change. Also, the research in this area should be encouraged to be developed with the participation of various stakeholders, e.g. rural persons who are not yet aware of the impact of climate change. 


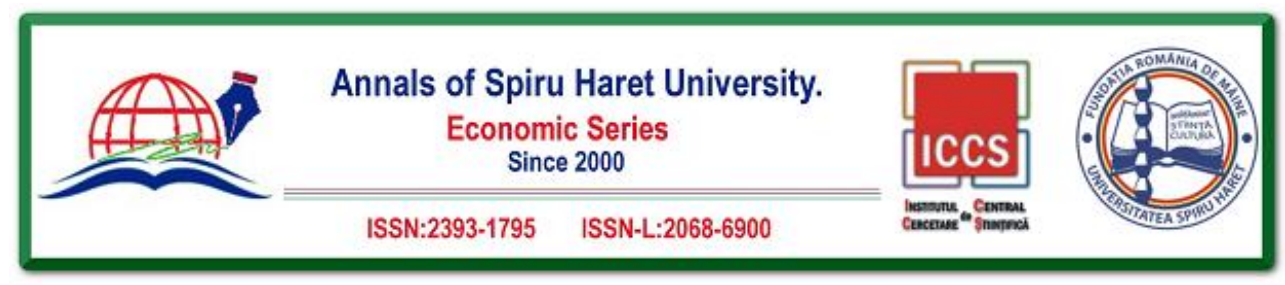

Issue 3/2018

There is a need for communication between the main actors involved in analysing climate change and the rural population. Understanding local perceptions and concerns will help the decision-maker to develop effective strategies for each rural location.

Some aspects resulting from this study are as follows:

- More education and awareness is needed for people in rural areas to understand the aspects related to climate change;

- A public awareness campaign on climate change should focus on causes, effects, adaptation, etc.;

- There is a need for widespread dissemination of information on climate change among rural population through various media channels;

- Awareness strategies should be innovative to reach various communities.

\section{Conclusions}

The added value of this paper is underlined by the use of a questionnaire about climate change in a survey developed in communities from rural Romania.

Climate change represents a threat to the environment, but also to the society and economy. The effects have been generated by the past and current lifestyle. Most of the economic activities, but also the daily behaviour of the individuals, contributed to this situation.

This paper analysed the results obtained by applying a questionnaire on the impact of climate change on rural households from Petrești commune, Dâmbovița County, Romania, in April 2018. It focused on how rural people relate to the climatic conditions with emphasis on the trend of major change in various aspects of the weather, sources used to find information on climate change, reliability level in the climate change information provided by various sources, the possibility to adopt measures to tackle the effects of climate change, and so on. The main conclusions of the research are:

- A high percent of respondents heard about climate change;

- Half of them perceived important changes in some aspects of the weather;

- Most of the information on climate change reached them via television;

- The highest confidence is in the information provided by specialists;

- A high proportion stated that they do not know if the changes in weather had or will have a influence on them;

- Of those already affected by climate change, a high ratio indicated a negative effect on the quantity and quality of crops, due to high temperatures / droughts, and increased incidence and severity of floods in gardens, orchards, and fields; 


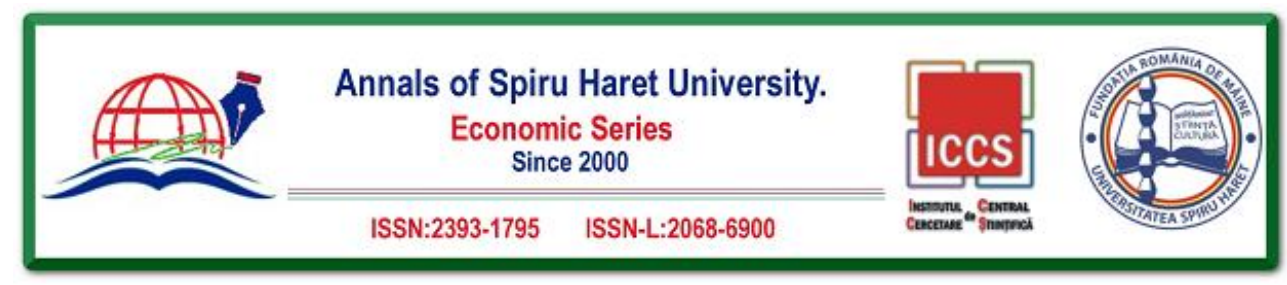

Issue $3 / 2018$

- A small percentage considered that measures can be taken to tackle the effects of climate change;

- The respondents considered businesses and industry as being responsible for taking measures to tackle the effects of climate change.

It is important that future research should consider the use of the questionnaire in a wider survey undertaken at national level. The results that will be obtained will underline the real situation regarding the impact of climate change on rural households from Romania. Also, they will provide decision-makers relevant conclusions that can be used to develop effective measures to tackle the effects of climate change.

\section{References}

1. Abaje, I. B., Sawa, B. A., Iguisi, E. O., \& Ibrahim, A. A. (2016). Impacts of Climate Change and Adaptation Strategies in Rural Communities of Kaduna State, Nigeria. Ethiopian Journal of Environmental Studies \& Management 9(1): 97-108.

2. Antwi-Agyei, P., Dougill, A., Fraser, E., \& Stringer, L. (2013). Characterising the Nature of Household Vulnerability to Climate Variability: Empirical Evidence from Two Regions of Ghana. Environment, Development and Sustainability, 15(4): 903-926.

3. Balteanu, D., Dragota, C. S., Popovici, A., Dumitrascu, M., Kucsicsa, G., \& Grigorescu, I. (2013). Land Use and Crop Dynamics Related to Climate Change Signals during the Post-Communist Period in South Oltenia, Romania. Proc. Rom. Acad., Series B, 15(3): 265-278.

4. Berhe, M. Hoag, D., Tesfay, G., Tadesse, T., Oniki, S., Kagatsume, M., \& Keske, C. (2017). The Effects of Adaptation to Climate Change on Income of Households in Rural Ethiopia. Pastoralism: Research, Policy and Practice, pp. 7-12.

5. Brown, H. C. P., \& Sonwa, D. J. (2015). Rural Local Institutions and Climate Change Adaptation in Forest Communities in Cameroon. Ecology and Society, 20(2): 6.

6. Constantinescu, A. Influenta schimbarilor climatice asupra Romaniei. Impact economic si masuri de prevenire la nivel regional, Universitara, 2018.

7. Cuculeanu, V., Tuinea, P., \& Balteanu, D. (2002). Climate Change Impacts in Romania: Vulnerability and Adaptation Options. GeoJournal, 57: 203-209.

8. Curseu, D., Popa, M., \& Sirbu, D. Climate Change Impact on Water Resources and Life Quality, Thirteenth International Water Technology Conference, IWTC 132009 , Hurghada, Egypt, 2009, www.iwtc.info/2009_pdf/1-7.pdf.

9. Dasgupta, P., Morton, J. F., Dodman, D., Karapinar, B., Meza, F., Rivera-Ferre, M. G., Toure Sarr, A., \& Vincent, K. E. Rural areas. In Field, C. B., V. R. Barros, D. J. Dokken, K. J. Mach, M. D. Mastrandrea, T. E. Bilir, M. Chatterjee, K. L. Ebi, Y. O. Estrada, R. C. Genova, B. Girma, E. S. Kissel, A. N. Levy, S. MacCracken, P. R. Mastrandrea, \& L. L. White (eds.). Climate Change 2014: Impacts, Adaptation, and Vulnerability. Part A: 


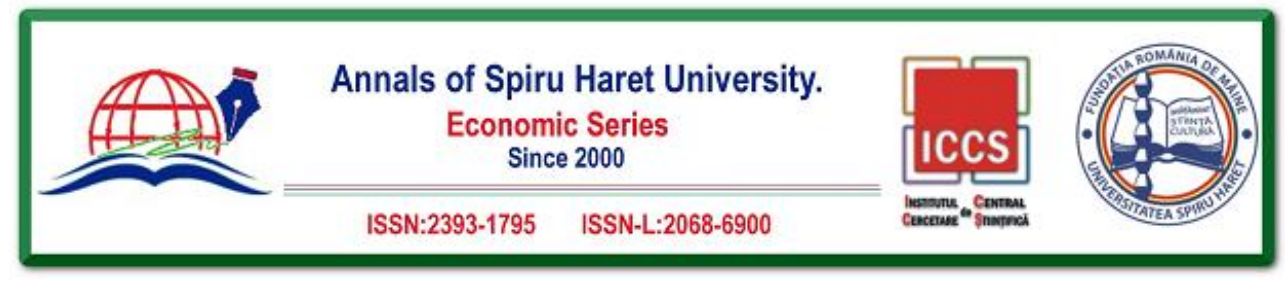

Issue 3/2018

Global and Sectoral Aspects. Contribution of Working Group II to the Fifth Assessment Report of the Intergovernmental Panel on Climate Change. Cambridge, United Kingdom and New York, NY, USA: Cambridge University Press. 2014, pp. 613-657.

10. Deressa, T., Hassan, R., \& Ringler, C. Assessing Household Vulnerability to Climate Change. The Case of Farmers in the Nile Basin of Ethiopia, The International Food Policy Research Institute (IFPRI) Environment and Production Technology Division, 2009, http://www.ifpri.org/publication/assessing-household-vulnerability-climate-change.

11. Dube, T., \& Phiri, K. (2013). Rural Livelihoods under Stress: The Impact of Climate Change on Livelihoods in South Western Zimbabwe. American International Journal of Contemporary Research, 3(5): 11-25.

12. Gurgu, E. (2010). The Impact on Climate and Environment Change - Renewable Energy Sector. Annals of Spiru Haret University, Economic Series, Vol. 10, No. 4.

13. Haque, A. N., Dodman, D., \& Hossain, M. (2014). Individual, Communal and Institutional Responses to Climate Change by Low-Income Households in Khulna, Bangladesh. Environment \& Urbanization, 26(1): 112-129.

14. Houghton, A., Austin, J., Beerman, A., \& Horton, C. (2017). An Approach to Developing Local Climate Change Environmental Public Health Indicators in a Rural District. Journal of Environmental and Public Health, 1.

15. Hurduzeu, G., Kevorchian, C., Gavrilescu, C., \& Hurduzeu, R. (2014). Hazards and Risks in the Romanian Agriculture Due to Climate Changes. Procedia Economics and Finance, 8 (2014): 346-352.

16. Ioan, I., \& Rădulescu, C. V. (2015). New Challenges for Agriculture within the Context of Climate Change. Theoretical and Applied Economics, Volume XXII (2015), No. 4(605), Winter, pp. 253-262.

17. Karfakis, P., Lipper, L., \& Smulder. M. The Assessment of the Socioeconomic Impacts of Climate Change at Household Level and Policy Implications, In: Building Resilience for Adaptation to Climate Change in the Agriculture Sector. Proceedings of a Joint FAO/OECD Workshop. Rome, 2012.

18. Kaushik, G., \& Sharma, K. C. (2015). Climate Change and Rural Livelihoods-Adaptation and Vulnerability in Rajasthan. Global NEST Journal, Vol. 17, No. 1, pp 41-49.

19. Ludena, C. E., \& Yoon, S. W. Local Vulnerability Indicators and Adaptation to Climate Change: A Survey, Inter-American Development Bank, Technical Note No. 857 (IDBTN857), Washington DC, 2015.

20. Luqman, M., Shahbaz, B., Majeed, M. Z., \& Raza, M. M. (2017). Impact of Climate Change on Rural Livelihoods - A Case of Hazara Region of Pakistan. J Agric. Res., 55(2): 441-452.

21. Maluleke, W., \& Mokwena, R. J. (2017). The Effect of Climate Change on Rural Livestock Farming: Case Study of Giyani Policing Area, Republic of South Africa. S. Afr. J. Agric. Ext., Vol. 45, No. 1, pp. 26-40.

22. Micu, D., Popovici, E. A., Havriş, L. E., \& Dragotă, C. S. (2017). Heat Stress-Crop Yields Interactions under Summer Warming Trends: Insights for the Southern Cropping 


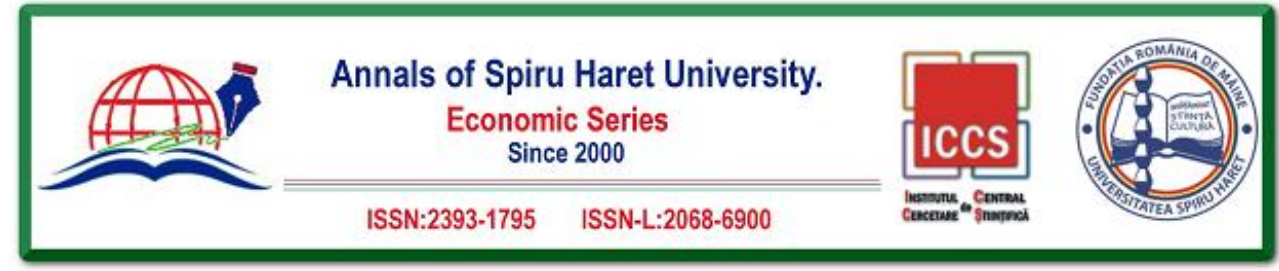

Issue 3/2018

Lowlands of Romania. Rev. Roum. Géogr./Rom. Journ. Geogr., 61(2): 169-192.

23. Mitrică, B., Mateescu, E., Dragotă, C. S., Grigorescu, I., Dumitraşcu, M., \& Popovici, E. A. (2015). Climate Change Impacts on Agricultural Crops in the Timiş Plain, Romania. Romanian Agricultural Research, No. 32.

24. Ncube, M., Madubula, N., Ngwenya, H., Zinyengere, N., Zhou, L., Francis, J. et al. (2016). Climate Change, Household Vulnerability and Smart Agriculture: The Case of Two South African Provinces. Jàmbá: Journal of Disaster Risk Studies, 8(2).

25. Ndhleve, S., Nakin, M. D. V., \& Longo-Mbenza, B. (2014). Rural Households' Awareness and Perceptions to Variability in Climatic Conditions in Rural South Africa. African Journal of Agricultural Research, 9(3): 418-424.

26. Ofoegbu, C., Chirwa, P., Francis, J., \& Babalola, F. (2017). Assessing Vulnerability of Rural Communities to Climate Change: A Review of Implications for Forest-based Livelihoods in South Africa. International Journal of Climate Change Strategies and Management, 9(03): 374-386.

27. Olabode, A. D, \& Adeleke, E. A. (2017). Rural Climate and Adaptive Strategies for Sustainable Food Security in Akungba-Akoko, Nigeria. Analele Universităţii din Oradea, Seria Geografie, Year XXVII, no. 1, (June), pp. 07-16.

28. Ontel, I., \& Vladut, A. (2015). Impact of Drought on the Productivity of Agricultural Crops within the Oltenia Plain, Romania. Geographica Pannonica, Volume 19, Issue 1, pp. 9-19.

29. Pettengell, C. Climate Change Adaptation Enabling People Living in Poverty to Adapt, Oxfam International Research Report, 2010, https://policy-practice.oxfam.org.uk/ publications/climate-change-adaptation-enabling-people-living-in-poverty-to-adapt111978

30. Poudel, S., Funakawa, S., \& Shinjo, H. Household Perceptions about the Impacts of Climate Change on Food Security in the Mountainous Region of Nepal. Sustainability 9,641 .

31. Riedy, C. (2017). Household Behavior Change for Climate Change Response. Journal of Integral Theory and Practice, 4(4): 103-120.

32. Rusu, T., Moraru, P., Coste, C., Cacovean, H., Chetan, F., \& Chetan, C. (2014). Impact of Climate Change on Climatic Indicators in Transylvanian Plain, Romania. Journal of Food Agriculture and Environment, 12(1): 469-473.

33. Seaman, J., Sawdon, G., Acidri, J., \& Petty, C. (2014). The Household Economy Approach. Managing the Impact of Climate Change on Poverty and Food Security in Developing Countries. Climate Risk Management, 4-5: 59-68.

34. Shrestha, R. P., Chaweewan, N., \& Arunyawat, S. (2017). Adaptation to Climate Change by Rural Ethnic Communities of Northern Thailand. Climate 5, 57.

35. Sima, M., Popovici, E. A., Bălteanu, D., Micu, D. M., Kucsicsa, G., Dragotă, C., \& Grigorescu, I. (2015). A Farmer-Based Analysis of Climate Change Adaptation Options of Agriculture in the Bărăgan Plain, Romania. Earth Perspectives, 2:5. 


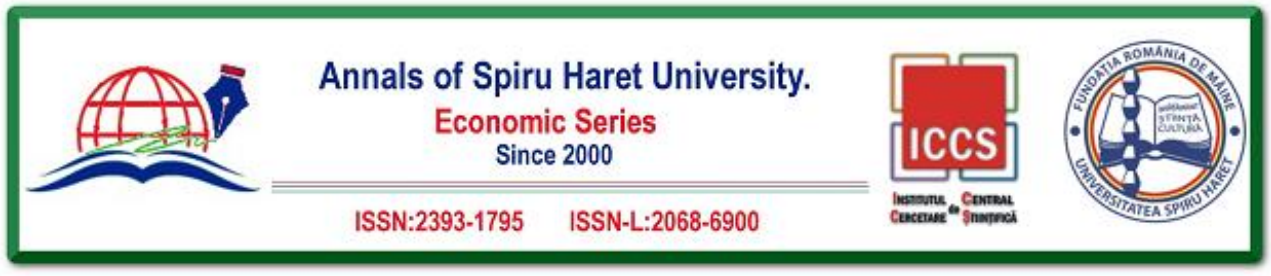

Issue 3/2018

36. Slave, C., \& Vizireanu, I. Climate Change in Relation to Agriculture, Agrarian Economy and Rural Development - Realities and Perspectives for Romania. 6th Edition of the International Symposium, the Research Institute for Agricultural Economy and Rural Development (ICEADR), Bucharest. 2015, pp. 162-166.

37. Umar, S., Musa, M. W., \& Tologbonse, E. B. (2014). Evaluating Resilience to Climate Change among Farming Households: The Coping Strategy Index (CSI) Approach. Proceedings of the 1st International conference on Drylands, pp. 245-250.

38. Zeleňáková, M., Purcz, P., Hlavatá, H., \& Blišt’an, P. (2015). Climate Change in Urban Versus Rural Areas, Procedia Engineering, 119, 1171-1180. 
